\title{
Lenin without dogmatism
}

\author{
Joe Pateman ${ }^{1,2}$
}

Published online: 8 April 2019

(c) The Author(s) 2019

\begin{abstract}
A longstanding criticism of Lenin is that his epistemological contributions to the theory of scientific socialism prompted the decline of Marxism in dogmatism and despotism in the twentieth century. According to this narrative, Lenin claimed to possess the objective truth, and he therefore refused to tolerate alternative perspectives. This article subjects these claims to a textual analysis, and it argues that they are erroneous. Lenin defends a fallibilist account of science that affirms the uncertainty of knowledge in the natural, philosophical and social sciences. This fallibilism pervades the text that supposedly showcases his intolerance, Materialism and Empirio-Criticism. Lenin's scientific socialism opposes rigid conceptions of socialism, and it encourages an atmosphere of democratic debate. Whilst Lenin's writings have their flaws, they are not the founding documents of Marxist dogmatism that they are often portrayed as being. Lenin is not the narrow-minded vulgariser of Marxism that he is routinely taken to be.
\end{abstract}

Keywords Lenin · Scientific socialism · Marxism · Dogmatism · Epistemology · Philosophy of science

\section{Do not debase our revolutionary science to the level of mere book dogma, do not vulgarise it. V. I. Lenin, "New Tasks and New Forces” (1977, vol. 8, 218).}

\section{Introduction}

In their most popular works Marx and Engels argued that the workers could emancipate themselves from the yoke of capital only if their revolutionary theory was scientific. In contrast to the utopian socialists, who focused on devising fantastical blueprints of the future society, the founders of Marxism emphasised the

Joe Pateman

Joepateman@yahoo.co.uk

1 University of Nottingham, University Park, Nottingham NG7 2RD, UK

292 Roseleigh Avenue, Mapperley, Nottingham NG3 6FH, UK 
importance of conducting a scientific analysis of society and its laws of development. In their view, science, and not metaphysical speculation, provided the most effective path to human freedom.

Today, however, it is widely thought that the theory of scientific socialism failed to emancipate society, and that it instead prompted the decline of Marxism into dogmatism and dictatorship. According to this narrative, the belief that Marxism was a science gave its followers the conviction that they had discovered the objective truth, and that they could 'guarantee methodological certainty and doctrinal orthodoxy' (Thomas 1976, 2). Having obtained the correct solutions to the major political problems, Marxists refused to tolerate alternative perspectives. They could not improve their scientific truths by subjecting them to the popular will or the ballot box, and they therefore disregarded democratic institutions: 'the Marxist scientists...set themselves up as arbiters of 'objective truth'- not only about how we do actually behave but also about how we ought to behave' (Femia 1993, 126).

Although the view that Marxism degenerated into intolerance and dogmatism is relatively uncontroversial, scholars disagree over whose ideas are responsible. One line of thought pins the blame on Marx himself. The prominent philosopher of science Popper $(1962,269)$ advanced one of the earliest and most detailed expositions of this view in his influential book, The Open Society and its Enemies. According to him, the feature of Marx's thought that encourages dogmatism is his belief in a precise and empirically based science of human organisation and development, modelled on Newtonian physics. In the same way that the physicist searches for causal natural laws, Marx claimed to uncover the inexorable economic 'laws' that govern history and society with 'iron necessity', unaffected by individual intentions or motives: 'Herein lies the source of the utter certitude (moral and political)' that actuates communists' (Femia 1993, 124-125).

After the discovery of Marx's earlier 'humanistic' writings, however, sympathetic interpreters began to increasingly question his responsibility for dogmatism. A new reading suggested that Marx actually provided the intellectual foundations for a more open, sophisticated and democratic Marxism.

A second narrative traces the roots of Marxist dogmatism back to Engels' rejection of utopian socialism and his popularisation of the term 'scientific socialism'. In his Anti-Duhring and Dialectics of Nature, Engels supposedly gave historical materialism an infallible basis by arguing that the laws of history are derived from the laws of nature (Ball 1984). The defenders of this view attempt to distance Marx from these texts by arguing that he either defends a more sophisticated version of scientific socialism, or that he rejects the concept entirely (Thomas 1976, 2).

A third line of thought challenges the association of Engels with dogmatism by arguing that he actually defends a fallibilist, anti-dogmatic conception of science (Sheehan 1993, 46-6). It also points out that his discussion of the utopians in AntiDuhring is primarily 'a work of praise' of their ideas, rather than a straightforward rejection. Whilst the supporters of this interpretation criticise Engels' 'indefensible' attempt to create a cosmological 'super-science', in addition to his infrequent scientism, they convincingly argue that his theory of scientific socialism endorses an atmosphere of open discussion (O’Neill 1996, 49-50, 54). 
Currently, one of the most popular and least contested narratives is that Lenin's uniquely epistemological contributions to the doctrine of scientific socialism are responsible for Marxist dogmatism (Ryan 2012, 18; Read 2005, 73; Harding 1996, 241; Boselager 1975, 32-33; Liebman 1975, 443; Ballestrem 1969, 307; Jordan 1967, 357-361; Wolfe 1965, 357-358; Meyer 1957, 298; Bochenski 1963, 1, 28, 48; Plamenatz 1954, 249). As the proponents of this narrative correctly point out, after the October Socialist Revolution, it was Lenin's interpretation of scientific socialism, rather than that of Marx and Engels, which became the supreme source of authority in the communist world and Third International. It was therefore Lenin, and not the founders, who had the largest impact upon the growth of 'methodological certainty' and 'doctrinal orthodoxy' in Marxism.

In this story of Lenin's scientific socialism as the 'genetic link' between Marxism and dictatorship, the text most often cited as evidence is Materialism and Empirio-Criticism (Bakhurst 2018: 115-117). It is in this work that Lenin develops his 'highly doctrinaire, not to say religious-dogmatic...approach to Marxist philosophy' (Tucker 1975, 639). It is here that he subjects his philosophical opponents to 'unbridled abuse', 'cheap mockery and invective'. It is here that the philosophical ideas of Engels 'are vulgarised and turned into cut-and-dried catechetical forms' (Kolakowski 1978, 721-727). Most crucially, it is in this text that Lenin introduces his notorious 'copy' theory of perception, which holds that human perceptions correctly and accurately 'reflect' the objective external world. Because Lenin thinks that people have an unmediated view of reality, he supposedly concludes that they can obtain certain knowledge about this reality (Service 1985, 181-182). In this way, Lenin provides the philosophical foundations for a dogmatic politics.

When Lenin published Materialism and Empirio-Criticism in 1909 it initially had little impact upon the development of Marxism. However, Hunt (1950, 212) argues that after the Soviet Union rose to prominence this text became 'the standard of intellectual orthodoxy, any departure from which could be represented as being as much an act of treachery to the revolutionary movement as were divergences on questions of party strategy and tactics'.

Liberals and conservatives are not the only proponents of this narrative, for the currents of Left-Bolshevism, Russian Menshevism, Left Communism, Western Marxism, and the Frankfurt school, provided the earliest criticisms of Lenin's philosophical intolerance (Bogdanov 1910, 178-183; Yushkevich 1910, 141; Pannekoek 1975; Korsch 1975, 117; 1970, 130; Horkheimer 1987, 184; Adorno 2008, 37). Some Marxist-Leninists advanced similar positions later on in their intellectual careers, usually after becoming somewhat disillusioned with the Soviet Union's 'repressive' practices (e.g. Cornforth 1980, 65-73).

The prevailing view then, is that whilst Lenin attempted to replicate the same lines of thought as his intellectually suppler predecessors, he could never achieve this successfully. His foray into the philosophy of science instead produced a dogmatic and crude distortion of the doctrine that Marx and Engels developed in a more subtle and sophisticated form. Lenin's vulgar, anti-democratic Marxism continues to highlight the intellectual, democratic virtues of Marx and Engels. His contributions 
to scientific socialism serve as a dangerous reminder of what Marxism can become in the mind of a less considerate thinker. ${ }^{1}$

By undertaking a more systematic, detailed, and complete analysis of Lenin's epistemological contributions to Marxism, this article rejects the narrative that his theory of scientific socialism is committed to a dogmatic, non-democratic politics. This narrative is based upon the claim that Lenin associates science with the attainment of certain, unquestionable knowledge. Not only does Lenin reject this association throughout his writings, such as in his Philosophical Notebooks. He explicitly denies that science provides certain knowledge in the very text that supposedly showcases his theoretical orthodoxy and intolerance. In Materialism and EmpirioCriticism Lenin defends a fallibilist account of science. ${ }^{2}$ Whilst he affirms the possibility of obtaining objective (i.e. true) knowledge of the world, he argues that this knowledge always remains uncertain, incomplete, and infinitely revisable. ${ }^{3}$ His conception of science therefore encourages a spirit of rational, democratic debate amongst political participants.

Whilst Lenin's texts on the philosophy of science may have their flaws, they are not the founding documents of Marxist dogmatism that they are often portrayed as being. Lenin is not the narrow-minded vulgariser of classical Marxism that he is routinely taken to be.

This article proceeds in three sections. The first section highlights the virtues of Lenin's scientific fallibilism by arguing that it is more convincing than Popper's influential account. Section two argues that Lenin extends this fallibilism to the philosophical and social sciences. He highlights unique obstacles to truth in politics and history, with the purpose of opposing dogmatism in socialist debate. The conclusion argues that the intellectual virtues of Lenin's scientific socialism can combat the rise of dogmatism in the present era of 'post-truth politics'.

\footnotetext{
1 Not everyone subscribes to the standard caricature. Anderson and Danayevskaya argue that Lenin developed a more flexible, dialectical understanding of the world and human knowledge in his 1914/15 Philosophical Notebooks (Anderson 1995, 71-72; Dunayevskaya 1973, Ch. 3). This narrative is unsatisfactory in two respects, however. Firstly, because Anderson and Dunayevsaya focus primarily upon Lenin's ontology, they treat his epistemology as a side issue of secondary importance. Secondly, there is little textual evidence to show that Lenin altered his philosophical views after 'rediscovering Hegel' in 1914 (Coombs 2016, 2; Michael-Matsas 2007, 112). The notion of an epistemological break has no basis, for Lenin chose to publish a second edition of Materialism and Empirio-Criticism in 1920, several years after he wrote his Philosophical Notebooks. In the preface Lenin (1977, vol. 14, 21) emphasises the importance of the text by stating that 'the present edition does not differ from the previous one. I hope that...it will prove useful as an aid to an acquaintance with the philosophy of Marxism, dialectical materialism'. Lenin therefore never rejected the 'vulgar materialism' of Materialism and Empirio-Criticism. On the contrary, he always believed that this work provided the definitive account of his philosophy. Mayer (1999) and Shandro (2014, 149-164) argue that Lenin views Marxism as a guide to practice, rather than a dogma. By focusing upon Lenin's political writings, however, they ignore the insights contained in his philosophical works.

${ }^{2}$ Lenin himself does not use the term 'fallibilism' or its cognate terms in his writings. The use of this term throughout this article reflects the present author's Popperian interpretative apparatus.

3 Bykova $(2018,246)$ and Bakhurst $(2018,110)$ defend a similar reading in their recent studies on Materialism and Empirio-Criticism. This article supports and expands upon their positions.
} 


\section{Lenin, Popper, and fallibilism}

Throughout his 1914/15 Philosophical Notebooks Lenin repeatedly affirms 'the finite, transitory, relative, conditional character of human cognition' (1977, vol. 38 , 207). During the course of analysing Hegel's ideas, he concludes that the human mind can only ever provide an approximate reflection of nature, rather than a perfect copy of it. In his 'Conspectus of Hegel's Science of the Logic', for instance, Lenin states that 'Knowledge is the reflection of nature by man. But this is not a simple, not an immediate, not a complete reflection'. On the contrary, "Man cannot comprehend $=$ reflect $=$ mirror nature as a whole , in its completeness, its "immediate totality," he can only eternally come closer to this, creating abstractions, concepts, laws, a scientific picture of the world' (1977, vol. 38, 182; see also 195). Later on, in his 'Conspectus of Hegel's Lectures on the History of Philosophy', Lenin argues that the universe is constantly developing, and this leads him to argue that 'if everything develops, does not that apply also to the most general concepts and categories of thought?' (1977, vol. 38, 254). Finally, in his celebrated essay 'On the Question of Dialectics', Lenin states that dialectical philosophy provides 'living, many-sided knowledge (with the number of sides eternally increasing), with an infinite number of shades of every approach and approximation to reality (with a philosophical system growing into a whole out of each shade)' (1977, 38, 360). These passages reject the possibility of obtaining certain knowledge.

One of the more sophisticated interpreters of Lenin, Neil Harding, provides two reasons as to why scholars should dismiss the relevance of Lenin's Philosophical Notebooks. Firstly, the text itself is little more than a set of scattered pronouncements and telegraphic one-liners. Lenin's remarks are discontinuous, they are hard to 'disentangle' from those of Hegel, and that they take the form of either 'summaries or cryptic comments at a high level of abstraction'. Secondly, Lenin's 1914 reflections were 'private ruminations', not intended for publication. They were not discovered and made public until 1928-1929 (Harding 1996, 234). Lenin supposedly chose not to publish his notebooks because they were "too explosive...too critical of his own "vulgar-materialist" standpoint of 5 years previously'. The fallibilist ideas contained in this work introduced a relativist element into Marxism that could undermine its claim to possess certain knowledge (Harding 1996, 237).

Harding's arguments for dismissing Lenin's Philosophical Notebooks are unconvincing. Firstly, the disjointed structure of the text provides no justification to reject it. Scholars regularly analyse documents with jumbled structures, and they often view them to be as important as published material. Secondly, the fact that Lenin never published his notebooks does not prove that he rejected the ideas contained within them, nor does it make them irrelevant. Several works by political thinkers were unpublished during their time, yet scholars still value them. Commentators on Lenin should treat his 'private ruminations' no differently. The political reasons that Harding outlines for Lenin suppressing the text are purely speculative, and impossible to prove via a textual analysis. He is therefore wrong 
to conclude that the ideas contained within Lenin's Philosophical Notebooks can 'hardly count as elements of Leninism as ideology' (Harding 1996, 234). In any case, Lenin's remarks on the fallibilism of scientific knowledge are not limited to his Philosophical Notebooks. He defends the same ideas in the text that is viewed as the classical document of his dogmatism.

Materialism and Empirio-Criticism (1977, vol. 14, 11) is, for the most part, an uncompromising and relentless assault upon 'the enemies of dialectical and historical materialism'. As such, the text is not a shining example of western intellectual values. Lenin constantly insults his philosophical opponents in the most vulgar fashion throughout, and he also misrepresents their views in order to lump them all together under the 'idealist' camp. ${ }^{4}$ Whilst the text therefore deserves some of its notoriety, it does not, however, affirm the possibility of obtaining certain knowledge.

In chapters two and three Lenin criticises the neo-Kantian view that it is impossible to obtain knowledge of a mind-independent world, and that the content of subjective human experience defines the limits of knowledge. He argues that this view can lead to irrationalism and dogmatism, for if people experience the world differently, and if truth is an 'organising form of experience', then there is no objective reality/standard to verify beliefs against, and anyone can assert that their (experienced based) belief is true. This subjectivism can, for instance, lead to the "the tolerance - the philistine, cowardly tolerance — of the dogmas regarding sprites, hobgoblins, Catholic saints, and the like' (CW 14: 128).

Lenin defends the materialist view that the external world exists independently of the human mind, and that the latter can approximately represent the world as it is. In contrast to Kant, he argues that 'things in themselves' are knowable, and as such, beliefs about the world can be objectively true, in the sense that they approximately reflect reality.

At the same time, however, Lenin develops his view that 'in the theory of knowledge, as in every other sphere of science, we must think dialectically'. That is, 'we must not regard our knowledge as ready-made and unalterable'. Lenin views the growth of knowledge to be an endless process, in which people gradually gain a more accurate picture of the world. The dialectical method describes how 'knowledge emerges from ignorance, how incomplete, inexact knowledge becomes more complete and more exact' (1977, vol. 14, 103).

Dialectics, Lenin $(1977$, vol. 14, 136) argues, 'recognises the relativity of all our knowledge, not in the sense of denying objective truth, but in the sense that the limits of approximation of our knowledge to objective, absolute truth are historically conditional'. That is, 'each step in the development of science adds new grains to the sum of absolute truth, but the limits of the truth of each scientific proposition are relative, now expanding, now shrinking with the growth of knowledge' (1977, vol. 14, 135). Lenin's epistemology acknowledges the generally progressive, objective character of scientific knowledge, whilst keeping it open to future revisions

\footnotetext{
4 Some commentators take the philosophical content of Lenin's work seriously (and recognize his fallibilism) while complaining that its style, rather than its substance, encouraged of the rise of dogmatism in Soviet philosophy (e.g. Wolfe 2001, 517; Bakhurst 1991, ch. 4; 2018, 115-118).
} 
and modification: 'by following the path of Marxian theory we shall draw closer and closer to objective truth (without ever exhausting it)' (1977, vol. 1, 143). The purpose of this dialectical conception of relative and absolute truth is to 'prevent science from becoming a dogma in the bad sense of the term, from becoming something dead, frozen, ossified' (1977, vol. 14, 136). It highlights the precarious, relative and limited nature of human knowledge, which reflects external reality only in the infinite process of approximation.

In the course of developing his theory of knowledge Lenin (1977, vol. 14, 135) also refers to the philosopher Joseph Dietzgen as a principal source of authority. This is significant, for scholars recognise Dietzgen's work specifically for his fallibilist attitude to science (O'Neill 1996, 63). Lenin highlights and defends this feature of Dietzgen's thought not only in Materialism and Empirio-Criticism, but also in a later article written to commemorate the 25th anniversary of his death. During a time when materialists were displaying dogmatic tendencies, Dietzgen emphasised 'the need to...understand that all human knowledge is relative' $(1977$, vol. 19, 80). By repeatedly describing Dietzgen as a key founder of scientific socialism, with almost the same level of prestige as Marx and Engels, Lenin makes it clear that fallibilism is a cornerstone of his philosophy.

In summary, Lenin's epistemology has two sides. On the one hand, he emphasises the dialectical character of knowledge, which is approximate, shifting and changing. On the other hand, he highlights the materialist side, which insists that knowledge is in fact objective. Critical commentators argue that these two sides are incompatible, and this underpins their reading of Lenin as a philosophical and political dogmatist. The preceding analysis shows that this is not the case. Lenin's point is that the recognition of science as a historical process of uneven advance towards more adequate levels of knowledge depends upon a reality that exists objectively and independently of cognition. That is, one can understand the continuous development of scientific knowledge only by recognising the necessary connection between these two sides. Lenin's position is not only consistent, but compelling as well. The commitment to fallibilism does require the recognition of an objective reality that the human mind can access and approximately represent in the form of objective knowledge.

According to Zizek (1997), the epistemology of Materialism and Empirio-Criticism advocates the same 'basic position' as Karl Popper, whose peculiar version of fallibilism once dominated discussions in the philosophy of science. This view is incorrect. ${ }^{5}$ Whilst Lenin's fallibilism is certainly similar to Popper's influential account, they each develop their ideas from different philosophical starting points. ${ }^{6}$ Lenin's account is also more convincing than Popper's. A comparison of their doctrines can show why this is the case.

\footnotetext{
${ }^{5}$ Zizek's claim is unconvincing not only because he provides no textual evidence, but because he also contradicts himself in another article, 'A plea for Leninist intolerance'. Here he highlights the dogmatism of Leninism by arguing that 'its universal truth can only be articulated from a thoroughly partisan position; truth is by definition one-sided.' As Zizek $(2002,550)$ concludes, 'this, of course, goes against the predominant doxa of compromise, of finding a middle path among the multitude of conflicting interests'. ${ }^{6}$ Contra Zizek (1997), Lenin's position does not belong 'in the Anglo-Saxon tradition of analytical philosophy'.
} 
A popular myth in the philosophy of science is that prior to Popper's contributions, scientific inductivism and dogmatism reigned supreme. The inductivist account of science holds that scientific knowledge begins with an observation, which is then followed by the proposal of a modest law that generalises the observed pattern. This means that a single observation can establish the existence of universal laws in nature. Inductivism led to dogmatism, since it could seemingly prove scientific theories to be true.

Popper tackled the problem of induction by arguing that an observation of nature cannot establish the existence of a universal law, for if one took the same observation at a different time or place, the results could be different. For example, an observation of the sun rising one morning does not prove the universal statement that it will rise every morning. This is because there may be no uniformity in nature. The laws of the natural world may change across time and space (Popper 1972, 7).

Popper claimed to have solved the problem of induction by arguing that science requires not induction, but deduction, according to which a single observation can falsify a universal statement. The observation of a black swan, for example, would disprove the universal statement that all swans are white. Popper's fallibilism argues that science proceeds via the formation of a hypothesis, which is then subjected to various tests. If the test falsifies the hypothesis, then it must be replaced by a new hypothesis, which will itself be tested. According to this account, scientific knowledge develops not through successful predictions, but through failed predictions (Popper 1972, 27).

Needless to say, philosophers of science have mostly rejected Popper's sceptical account of the problem of induction. One of the main objections is that his theory fails to describe the historical development of real world science. Several valid scientific theories encountered observational claims that were inconsistent with them, and if scientists had followed Popper's deductivist methodology, they would have rejected these theories in their infancy. Nevertheless, scientists did not reject these theories, and this benefitted science in the long run. Few would now deny that science, understood as a critical and rational mode of enquiry, requires and does assume a degree of uniformity in nature (Chalmers 1982, 66). It cannot and does not progress upon the basis of Popper's philosophical scepticism.

The philosophical basis of Lenin's (1977, vol. 19, 24) fallibilism is not scepticism, but dialectical materialism, which he defines as 'the doctrine of the relativity of the human knowledge that provides us with a reflection of eternally developing matter'. Lenin's philosophy of science is dispersed throughout his writings, and as such, it is impossible to discern in a straightforward manner. It is still worth reconstructing the fundamentals of his doctrine, however, for it sheds light on the fallible nature of the sciences.

Like Popper, Lenin (1977, vol. 14, 305) is critical of the inductivist approach to science, for he points out that the development of scientific knowledge is characterised by the 'abrupt break-down of old established concepts'. Theories in biology, chemistry and physics are constantly falsified, 'for with each step in the development of science new aspects are discovered' (1977, vol. 14, 129). Whilst, therefore, the world and its laws can be known to man, they can 'never be known to him with finality' (1977, vol. 14, 189). 
Lenin's critique of scientific inductivism is not, however, based upon Popper's scepticism concerning the uniformity of nature. He criticises 'fashionable bourgeois scepticism' for its 'tendency to despise generalisations' and 'hide from the "laws" of historical development'. Lenin (1977, vol. 14, 155) believes that there is a degree of uniformity in nature, and that some truths are therefore beyond reasonable doubt. He points out that some natural laws are 'accepted by all despite the host of seeming contraventions and deviations shown in the medley of individual cases, and the search for corrections and supplements to them' (1977, vol. 20, 201).

What Lenin grants to Popper's critique of induction is that the observation of regularities is insufficient in proving the existence of causal relationships: 'the simplest truth obtained in the simplest inductive way is always incomplete, for experience is always unfinished. Ergo: the connection of induction with...the relativity of all knowledge' (1977, vol. 38, 180). In his view, one can identify causal relations and thereby acquire scientific knowledge only through 'practice, experiment and industry' (1977, vol. 14, 170).

Critical realism has recently reiterated Lenin's critique of induction (Bhaskar 1989). Science does not develop by observing regularities in nature. The natural world is an open system, which means that the events that take place within it do not always occur regularly, and nor are they always observable. Almost every event in the natural world results from a combination of causal mechanisms, and they are characterised by hardly any regularities (1977, vol. 21, 54). Only the controlled conditions created by experiments can attempt to investigate and isolate the particular causal relationships that operate in nature. They do this by constructing closed systems that try to remove or minimise the influence of unwanted external factors. The problem of establishing a completely closed system through experimentation provides the foundation of Lenin's fallibilism.

Lenin proceeds from the assumption that all objects in the universe are interconnected, and that 'if we are to have a true knowledge of an object we must look at and examine all its facets, its connections and "mediacies". He introduces his fallibilism by arguing that a complete examination of all these connections 'is something we cannot ever hope to achieve completely'. Lenin still emphasises the importance of striving to gain the most accurate and detailed picture, however, for 'the rule of comprehensiveness is a safeguard against mistakes and rigidity' (1977, vol. 32, 94).

One reason as to why the interconnectedness of nature prohibits the discovery of certain knowledge, in Lenin's view, is that it is impossible to ensure experimental closure. He illustrates this point by giving the example of Boyle's law, which states that the pressure and volume of a gas have an inverse relationship. If the volume of gas increases, then its pressure decreases, and vice versa. However, this law only holds true under controlled conditions, wherein the temperature is held at a constant. As such, "the "grain of truth" contained in this law is only absolute truth within certain limits. The law, it appears, is a truth "only approximately" (1977, vol. 14, 134-135). According to Lenin, the causes and effects identified in experiments and small-scale observations are different in larger environments, where the interconnections are innumerable and even harder to establish, and this means that 'the all-sidedness and all-embracing character of the interconnection of the world... is only one-sidedly, fragmentarily and incompletely expressed by causality' (1977, 
vol. 38, 159). Every law 'always somewhat simplifies the objective connection of the phenomena of nature, reflecting it only approximately, artificially isolating one or another aspect of a single world process' (1977, vol. 14, 156). In other words, 'law, every law, is narrow, incomplete, [and] approximate' (1977, vol. 38, 151).

The problems involved in obtaining non-revisable knowledge through experimentation are not, for Lenin, of a purely practical nature. He argues that it is impossible in principle. Scientists cannot control the conditions that can influence the result of an experiment because there are an infinite number of properties in nature, which can never be exhausted by scientific knowledge. Firstly, he believes that all objects contain an infinite number of qualities. A tumbler, for example, 'is assuredly both a glass cylinder and a drinking vessel. But there are more than these two properties, qualities or facets to it; there are an infinite number of them' (1977, vol. 32, 93). Secondly, he argues that nature also possesses a quantitative infinity. All objects can be divided an infinite number of times, hence his belief that 'the atom can be explained as resembling an infinitely small solar system', and that 'nature is infinite, just as its smallest particle (including the electron) is infinite'. This means that the " "essence" of things, or "substance," is also relative; it expresses only the degree of profundity of man's knowledge of objects' (1977, vol. 14, 260, 262). Because one can always obtain a deeper level of understanding of objects, the infinite diversity of properties in nature prohibits the attainment of infallible knowledge of the natural world: 'Human thought goes endlessly deeper from appearance to essence, from essence of the first order, as it were, to essence of the second order, and so on without end' (1977, vol. 38, 251-252). Thus, whilst 'yesterday the profundity of this knowledge did not go beyond the atom, and today does not go beyond the electron and ether', dialectical materialism 'insists on the temporary, relative, approximate character of all these milestones in the knowledge of nature gained by the progressing science of man' (1977, vol. 14, 262).

As Lenin believes that it is impossible to obtain experimental closure, he concludes that it is 'precisely (and only)' by repeating experiments 'a thousand million times' that one can approach absolute knowledge (1977, vol. 38, 216). This means that 'the criterion of practice', i.e. scientific empirical study and investigation, 'can never, in the nature of things, either confirm or refute any human idea completely. This criterion too is sufficiently "indefinite" not to allow human knowledge to become "absolute", (1977, vol. 14, 142-143).

Lenin's critique of induction highlights the fallacy of using a limited number of observations to prove a universally valid claim, when the quantifier ranges across an infinitely large domain. Whilst Popper views the infinity of the realm of natural processes, objects and events only in terms of their spatial and temporal location, Lenin understands it in terms of their infinite number of properties.

Lenin's fallibilist account of science has its flaws. For example, his claim that it necessary to repeat experiments 'a thousand million times' in order to achieve certain knowledge is confused. A consistent fallibilist would argue that theories always remain uncertain, no matter how many times people test them. Nevertheless, Lenin's view that the impossibility of obtaining experimental closure explains the fallible character of scientific knowledge is more convincing than Popper's account. The problem of induction in science is not Popper's scepticism regarding the uniformity 
of nature, but the interconnectedness and variety of the natural world that Lenin identifies. Lenin also provides a more convincing explanation than Popper as to why scientists undertake and repeat experiments. Efforts to limit the variety of properties in nature constitute the rational for controlling and repeating experiments. Scientists attempt to achieve experimental control not in order to check the effects of place and time, but in order to limit the amount of external variables that can affect the results. Scientists repeat experiments not in order to obtain more cases for inductive inference, but to ensure that previous experiments were adequately controlled. Scientists conduct new experiments in order to investigate scientific hypotheses in untested conditions, rather than in different places and times. Although it will never be known for certain, this may explain why Popper (cited in Colletti 1996, 51), in a private letter from 1970, wrote that 'Lenin's book on Empirio-Criticism is, in my opinion, truly excellent'.

\section{Lenin's fallibilist conception of philosophy and social science}

Critical perspectives tend to disregard Lenin's views on science by arguing that they bear no relation to his partisan 'philosophy of certainty', which is immune to criticism or revision (Harding 1996, 241). Even a more sympathetic commentator, David-Hillel Ruben (1977, 189), argues that 'for Lenin, philosophical materialism retains a certain imperviousness to the results of the special sciences'. This narrative is unconvincing for three reasons. First of all, Lenin argues that the ontology of dialectical materialism is so general that even bourgeois scientists subscribe to it. Modern physics is 'giving birth to dialectical materialism', 'not consciously, but instinctively, not clearly perceiving its "final goal", but drawing closer to it gropingly, unsteadily, and sometimes even with its back turned to it' (1977, vol. 14, 313). Lenin's main point, which he further develops in his article On the Significance of Militant Materialism, is that several natural scientists are dialectical materialists without even knowing it (1977, vol. 33, 227-236). This shows that Leninist philosophy can encompass a variety of perspectives. It is not committed to a specific political platform, let alone a dogmatic politics.

Secondly, several passages in Materialism and Empirio-Criticism defend a fallibilist conception of philosophical knowledge. In chapter four for instance, Lenin argues that 'Marx, Engels and J. Dietzgen did not worry about the elementary truths of materialism, which had been cried by the hucksters in dozens of books'. During the historical period in which the founders of scientific socialism developed their philosophical ideas, they 'devoted all their attention to ensuring that these elementary truths should not be vulgarised, should not be over-simplified, should not lead to stagnation of thought'. They were 'more concerned to dissociate themselves from the vulgarisation of the elementary truths of materialism than to defend these truths themselves' (1977, vol. 14, 243).

Thirdly, Lenin $(1977$, vol. 14, 21) himself rejects the idea that science and philosophy are unrelated, for in the preface to the second edition of Materialism and Empirio-Criticism he states that the purpose of his book is to elucidate 'the philosophical conclusions from the recent discoveries in natural science'. Like Marx, 
Engels and Dietzgen before him, Lenin believes that a genuine philosophy should base its propositions not upon metaphysical speculation, but upon the latest findings in the natural sciences. Since Lenin $(1977$, vol. 14, 185) recognises that 'the teachings of science on the structure of matter, on the chemical composition of food, on the atom and the electron, may and constantly do become obsolete', he argues that Marxists should revise the propositions of dialectical materialism in accordance with these new discoveries: 'Engels says explicitly "with each epoch making discovery even in the sphere of natural science ["not to speak of the history of mankind"], materialism has to change its form"". Accordingly, "a revision of the "form" of Engels' materialism, a revision of his natural-philosophical propositions is not only not "revisionism," in the accepted meaning of the term, but, on the contrary, is demanded by Marxism' (1977, vol. 14, 251). Lenin sought to accomplish this task for his own time in chapter five of Materialism and Empirio-Criticism.

By arguing that even the natural sciences are fallible, and by then stressing the dependency of dialectical materialism upon findings in the natural sciences, Lenin undermines the strategy of proclaiming absolute truths in the sphere of philosophy by appealing to such truths in the natural sciences. His emphasis upon the inseparability of natural science and philosophy therefore reinforces his opposition to dogmatism.

Lenin also highlights the unique obstacles to certain knowledge in the social sciences that make them more fallible than the natural sciences. His purpose is to emphasise the inevitability of error in socio-political analysis, and to therefore oppose dogmatic tendencies in the Marxist movement.

Lenin's philosophy of natural science assumes that the natural world is filled with mostly non-sentient, non-conscious forces and elements, and he therefore argues that the laws of nature display a high degree of uniformity over time and space. His philosophy of social science, by contrast, recognises that the social world is filled with conscious, intelligent, and relatively autonomous beings, and he concludes from this that the laws of society are less uniform and harder to identify (1977, vol. 1, 159). Under capitalism, for instance, the productive activity of every individual modifies the economic system in a specific way. Because there are billions of people simultaneously producing things across the globe, 'the sum-total of these changes in all their ramifications in the capitalist world economy could not be grasped even by seventy Marxes' $(1977$, vol. 14, 325). Lenin therefore 'rejects the very idea that the laws of economic life are one and the same for the past and the present'. He instead believes that 'every historical period has its own laws' $(1977$, vol. 1, 167). Lenin also argues that 'earlier economists misunderstood the nature of economic laws when they likened them to the laws of physics and chemistry'. In his view, 'a more thorough analysis shows that social organisms differ among themselves as fundamentally as plants or animals'. This high degree of variation in social phenomena makes truth claims in the social sciences more uncertain than the natural sciences (1977, vol. 1, 167).

Lenin argues that the historical sciences are particularly fallible, for whilst he views the development of history to be a law-governed process, the observed events rarely repeat themselves with the same consistency as natural phenomena. This means that 'it is by no means precluded, but, on the contrary, presumed, that certain 
periods of development may display peculiarities in either the form or the sequence of this development' (1977, vol. 33, 477).

In Lenin's view, another insurmountable obstacle to certain knowledge in the historical sciences is that the evidence on past social structures and events is often non-existent, inaccessible, or insufficient. This hinders the explanatory power of historical materialism, which requires empirical data in order to establish the basesuperstructure relation. 'Lack of factual material made it impossible to apply this method to an analysis of certain very important phenomena in ancient European history-for instance, that of gentile organization', which, as a result, 'remained a riddle' (1977, vol. 1, 150).

Even when the historical data is available, Lenin argues that the historian can never assimilate it all, and this limits the validity and scope of their analysis. In his review of Bogdanov's book, A Short Course of Economic Science, for instance, Lenin commends the considerable yet non-exhaustive range of references, before commenting that 'It would be impossible to outline, in any course, no matter how extensive, all the data of modern science on all periods of economic development and on the history of economic views from Aristotle to Wagner' (1977, vol. 4, 50).

Lenin argues that the epistemological problems of the historical sciences prohibit the attainment of non-revisable knowledge in this sphere. He therefore rejects 'that most banal and vulgar accusation', that 'Marxists profess the immutability of an abstract historical scheme'. In his view, 'no Marxist has ever regarded Marx's theory as some universally compulsory philosophical scheme of history' (1977, vol. 1, 192). Like Engels before him, Lenin opposes the socialist philosopher E. Duhring, who, 'on the most complex questions of science in general, and of historical science in particular... scattered words right and left: ultimate, final and eternal truth'. According to him, the only truths that can be established in the historical sciences are mundane facts and trivialities that cannot be utilised in the service of a dogmatic politics: "Napoleon died on May 5, 1821," says Engels...explaining to Duhring what one who claims to discover eternal truths in the historical sciences has to confine himself to, what "platitudes" he has to be satisfied with' (1977, vol. 14, 133, 132).

Lenin believes that politics is the most fallible science, however, for it inherits all of the problems of the other social and natural sciences, whilst possessing unique problems of its own. In the first place, whereas scientists can accurately predict when natural events will occur, the same kinds of predictions are impossible in the more 'difficult and complex science' of revolutionary politics, where the complexity of events precludes the possibility of accurate forecasting (1977, vol. 27, 198). Whilst Lenin argues that it is "natural for children to "understand" science to mean something that can determine in what year, spring, summer, autumn or winter' capitalism will collapse, he believes that these are 'ridiculous, vain attempts to ascertain what cannot be ascertained' (1977, vol. 27, 327).

In the second place, whereas various natural phenomena manifest themselves through a predictable and regular sequence of events, Lenin believes that one will rarely observe the same degree of uniformity in politics. He argues that revolutionary periods are particularly hard to discern and predict: "to say "a revolution has taken place in one country, so now it must take place in Germany"-is false 
reasoning. There is a tendency to form an order of sequence, but this cannot be done'. One cannot know 'whose turn it will be, when it will take place, and with what degree of success' (1977, vol. 24, 267). In the preface to the second edition of The Development of Capitalism in Russia Lenin argues that societies are complex organisms, and as such, 'infinitely diverse combinations of elements of this or that type of capitalist evolution are possible'. He concludes that it is futile to try and predict with certainty which direction Russian society will take:

In a revolutionary epoch, life in a country proceeds with such speed and impetuosity that it is impossible to define the major results of economic evolution in the heat of political struggle... How this struggle will end, what the final result of the first onset of the Russian Revolution will be-it is at present impossible to say (1977, vol. 3, 34).

The political conclusions that Lenin draws from the unique epistemological problems of the social sciences highlights how far his theory of scientific socialism is opposed to the dogmatism and intellectual orthodoxy that it is commonly accused of generating. Nowhere are these conclusions clearer than in chapter six of Materialism and Empirio-Criticism. Here Lenin argues that 'the whole attempt' to establish political truths by appealing to truths in the natural sciences 'is worthless from beginning to end', for the laws of the natural sciences, when 'applied to the sphere of the social sciences, are empty phrases'. This is because 'an enquiry into social phenomena and an elucidation of the method of the social sciences cannot be undertaken with the aid of these concepts'. Whilst Lenin believes that "nothing is easier than to tack an "energeticist" or "biologico-sociological" label on to such phenomena as crises, revolutions, the class struggle and so forth', he argues that there is nothing 'more sterile, more scholastic and lifeless than such an occupation' (1977, vol. 14, 328).

Lenin's purpose in stressing the fallibilism of the social sciences is to emphasise the importance of openness and tolerance in political debate. Whilst 'history as a whole, and the history of revolutions in particular, is always richer in content, more varied, more multiform, more lively and ingenious than is imagined by even the best parties', he believes that 'In politics it is even harder to know in advance which methods of struggle will be applicable and to our advantage in certain future conditions' (1977, vol. 31, 95-96). During revolutionary periods Lenin (1977, vol. 17, 42-43) argues that it is "natural and inevitable that there should emerge "a revaluation of all values", a new study of fundamental problems, a new interest in theory, in elementals, in the ABC of politics'. When Rosa Luxemburg therefore accused him of permanently closing down the avenues of inner party debate, he replied that her criticism had no basis: 'She puts in my mouth commonplaces, general principles and conceptions, absolute truths, and tries to pass over the relative truths, pertaining to perfectly definite facts, with which alone I operate' (1977, vol. 7, 476). Lenin did not see the reduction of inner-party democracy as a universal principle, valid for all times and places, as Luxemburg seemed to think. He instead saw it as a temporary response to the autocratic circumstances of tsarist Russia, where inner-party democracy was infeasible (Mayer 1999, 45). 
It would be wrong to conclude that Lenin's fallibilist conception of political science rejects the maintenance of fundamental political principles in Marxism. On the contrary, a distinctive hallmark of Lenin's writings is his militant defence of these principles against various forms of 'revisionism'-a pejorative term that he popularised. In his aptly titled article Our Programme, for instance, Lenin rejects Bernstein's amendments to Marxism on the basis that they failed to advance 'the science which Marx and Engels enjoined us to develop'. He immediately anticipates the 'flood of accusations' that his anti-revisionism would (and still) bring: 'The shouts will rise that we want to convert the socialist party into an order of "true believers" that persecutes "heretics" for deviations from "dogma," for every independent opinion' (1977, vol. 4, 211). Lenin's summary of these 'trenchant phrases', which are still repeated today, is that 'there is not a grain of truth or sense in them'. His first line of defence is that a successful revolutionary movement requires a revolutionary theory. If all principles are open to question then the mass organisations will fracture and dissipate into a multitude of insignificant groupings. Without a stable set of underlying assumptions it will be difficult for the various sections of the working population to unite into an effective force. Lenin's second and more persuasive argument is that 'to defend such a theory, which to the best of your knowledge you consider to be true, against unfounded attacks and attempts to corrupt it is not to imply that you are an enemy of all criticism'. In other words, the protection of theoretical fundamentals is not incompatible with the freedom to criticise and debate political issues. He goes on to state that:

We do not regard Marx's theory as some thing completed and inviolable; on the contrary, we are convinced that it has only laid the foundation stone of the science which socialists must develop in all directions if they wish to keep pace with life (1977, vol. 4, 211).

In conclusion, Lenin $(1977$, vol. 4, 212) argues that 'an independent elaboration of Marx's theory is especially essential' for all socialists, for 'this theory provides only general guiding principles', which must be applied differently in accordance with the peculiar characteristics of each country. The notion that Marxism requires an 'independent elaboration' is particularly anti-dogmatic, for individuals will inevitably develop different policies.

Lenin puts forward a similar argument in his article Uncritical Criticism. Here he states that the commitment to fundamental principles should not mean a commitment to dogmatism. 'Let us not believe that orthodoxy means taking things on trust, that orthodoxy precludes critical application and further development, that it permits historical problems to be obscured by abstract schemes.' In Lenin's view, Marxists are not required to subscribe to any belief without reason, and they should not accept any formulation as so authoritative that it cannot be modified or rejected as the result of discussion. 'If there are orthodox disciples who are guilty of these truly grievous sins', says Lenin, then 'the blame must rest entirely with those disciples and not by any means with orthodoxy, which is distinguished by diametrically opposite qualities'. He goes on to say that 'to accept anything on trust, to preclude critical application and development, is a grievous sin; and in order to apply and develop, "simple interpretation" is obviously not enough' (1977, vol. 3, 630). This belief underlies his 
view that even 'Engels was not infallible. Marx was not infallible', for some of their ideas had been made antiquated by historical developments (1977, vol. 35, 269-272; vol. 20, 433). Lenin (1977, vol. 3, 33) warns against uncritically relying upon the classics for contemporary political solutions, for 'only hopeless pedants could set about solving the peculiar and complex problems arising merely by quoting this or that opinion of Marx about a different historical epoch'.

Lenin directs his fiercest criticisms against the socialists who, in his view, ignored the necessity of critically applying and developing the fundamental principles of Marxism. In the first place, he chastises the 'old Bolsheviks', who 'played so regrettable a role in the history of our Party by reiterating formulas senselessly learned by rote instead of studying the specific features of the new and living reality' (1977, vol. 24, 44).

Lenin also criticises the Left Communists- 'the doctrinaires of the revolution'for their refusal to recognise that political principles must change in accordance with the changing historical conditions of each particular country. He reminds the 'infantile' leftists that 'any truth, if "overdone" (as Dietzgen Senior put it), if exaggerated, or if carried beyond the limits of its actual applicability, can be reduced to an absurdity, and is even bound to become an absurdity under these conditions' (1977, vol. 31, 62).

It is the orthodox Marxists of the Second International, however, who receive the brunt of Lenin's criticism. For although they recognised the necessity of adopting flexible tactics in theory, they 'proved to be so undialectical in practice, so incapable of taking into account the rapid change of forms and the rapid acquisition of new content by the old forms'. 'The principal reason for their bankruptcy', in Lenin's view, was that they refused to acknowledge the tactical changes made necessary by historical development, and they therefore 'continued to repeat simple and, at first glance, incontestable axioms that had been learned by rote, like: "three is more than two"". As Lenin points out, however, "politics is more like algebra than arithmetic, and still more like higher than elementary mathematics'. Thus, whilst the socialist movement undertook a qualitative change, and whilst 'a new symbol, the "minus" sign... appeared in front of all the figures', the orthodox Marxists 'stubbornly continued (and still continue) to persuade themselves and others that "minus three" is more than "minus two"" (1977, vol. 31, 102).

Whilst Lenin's criticisms of old Bolshevism, Left Communism, and Second International Marxism may not convince everyone, they are founded upon his conviction that Marxism is not a body of ready-made answers, but a scientific theory that should be used to inform an independent and subjective analysis of society. The materialist dialectic highlights the complex, unpredictable and non-linear character of historical development, and this means that Marxism must revise itself in accordance with this development. The political principles of scientific socialism therefore need to be as temporary as the social phenomena it reflects:

Our doctrine-said Engels, referring to himself and his famous friend- is not a dogma, but a guide to action. This classical statement stresses with remarkable force and expressiveness that aspect of Marxism which is very often lost sight of. And by losing sight of it, we turn Marxism into something one-sided, 
distorted and lifeless; we deprive it of its life blood; we undermine its basic theoretical foundations-dialectics, the doctrine of historical development, allembracing and full of contradictions; we undermine its connection with the definite practical tasks of the epoch, which may change with every new turn of history...It is precisely because Marxism is not a lifeless dogma, not a completed, ready-made, immutable doctrine, but a living guide to action, that it was bound to reflect the astonishingly abrupt change in the conditions of social life (1977, vol. 17, 39-42).

Lenin believes that the Russian revolution itself provided 'an instructive practical refutation of all doctrinarism', for its development turned out to be 'more original, more peculiar, (and) more variegated than anyone could have expected' (1977, vol. 31,104 ; vol. 24, 44). As a direct consequence of this period, "the "revaluation of all values" in the various spheres of social life led to a "revision" of the most abstract and general philosophical fundamentals of Marxism' (1977, vol. 17, 42-43). It was his political experience that encouraged Lenin to proudly proclaim, in the course of outlining The Three Sources and Three Component Parts of Marxism, that 'the history of philosophy and the history of social science show with perfect clarity that there is nothing resembling "sectarianism" in Marxism, in the sense of its being a hidebound, petrified doctrine'.

Lenin thought that the construction of socialism in Russia highlighted the incompleteness of Marxist political science more than anything else. Whilst there had been several bourgeois revolutions before, there had been no socialist revolutions, and this meant that there were few texts to refer to. The masses were making history, and mistakes were therefore unavoidable. Lenin often emphasised that 'We do not claim to be infallible; many of our decrees are bad', and on multiple occasions he acknowledged that the task of building communism would 'inevitably entail a vast number of experiments, a vast number of steps, a vast number of alterations, a vast number of difficulties... because we have no experience of this' (1977, vol. 27, 312, 410-411). An analysis of these political experiments and the problems they involved would dominate Lenin's writings until his death in 1924.

\section{Conclusion}

One of the great myths about Lenin is that his commitment to science entailed a commitment to dogmatism and theoretical orthodoxy. This claim has no textual or philosophical basis. Lenin's defence of scientific socialism is founded upon a fallibilist conception of science that defends a spirit of toleration and open criticism in political debate. This fallibilism permeates the text that is often viewed to be the quintessential work of his dogmatism, Materialism and Empirio-Criticism.

Liebman contends that the Third International supported an atmosphere of free discussion and criticism that opposed 'dogmatic rigidity' under Lenin's guidance: 'the use of sergeant-major methods was no more inherent in the Leninist Comintern than was monolithism' (Liebman 1975, 395, 401-403). This article has argued that 
this openness resulted from a commitment to a fallibilist account of social scientific enquiry. Whilst the Third International may have had its faults during this period, the appeal to Lenin's ideas in order to inform political activity was not a source of dogmatism, but it's opposite. ${ }^{7}$ According to O'Neill $(1996,63)$, the alleged closure of that debate and the development of a political and social scientific orthodoxy was a 'later post-Leninist phenomenon'.

With the rise of the 24 hours news cycle, unbalanced news reporting, and social media, more political commentators now argue that Western societies are living in an era of 'post-truth politics', a political culture in which debates are dominated by appeals to human emotion and irrationality rather than facts and rational argument. The increasingly anti-scientific tone of this discourse-as seen, for instance, in the debates concerning the Brexit referendum and the 2016 U.S presidential election-carries the danger of degenerating into forms of dogmatic assertion that are immune to rational debate. The intellectual virtues underlying Lenin's philosophy of science-his anti-orthodoxy, his anti-dogmatism and his insistence on debates that meets the standards of rational enquiry, are now in as much need of being reclaimed as the core virtues of politics as they were when he first defended them.

Conflict of interest The author declares that they have no conflict of interest.

Open Access This article is distributed under the terms of the Creative Commons Attribution 4.0 International License (http://creativecommons.org/licenses/by/4.0/), which permits unrestricted use, distribution, and reproduction in any medium, provided you give appropriate credit to the original author(s) and the source, provide a link to the Creative Commons license, and indicate if changes were made.

\section{References}

Adorno, T. (2008). Lectures on negative dialectics: Fragments of a lecture course 1956/1966. Cambridge: Polity Press.

Anderson, K. (1995). Lenin, Hegel, and Western Marxism. Chicago: University of Illinois Press.

Bakhurst, D. (1991). Consciousness and revolution in soviet philosophy: From the Bolsheviks to Evald Ilyenkov. Cambridge: Cambridge University Press.

Bakhurst, D. (2018). On Lenin's materialism and empiriocriticism. Studies in Eastern European Thought, $70(2-3), 107-119$.

Ball, T. (1984). Marxian science and positivist politics. In T. Ball \& J. Farr (Eds.), After Marx (pp. 235261). Cambridge: Cambridge University Press.

Ballestrem, K. (1969). Lenin and Bogdanov. Studies in Soviet Thought, 9(4), 283-310.

Bhaskar, R. (1989). A realist theory of science. Hempstead: Harvester Wheatsheaf.

Bochenski, J. (1963). Soviet Russian dialectical materialism. Dordrecht: D. Reidel Publishing Company.

Bogdanov, A. (1910). Faith and science. Cited in Service, R. (1985). Lenin: A political life (Vol. 1). Houndsmills: Macmillan.

Boselager, W. (1975). The soviet critique of neo-positivism. Boston: D. Reidel Publishing Company.

Bykova, M. F. (2018). Lenin and the crisis of Russian Marxism. Studies in Eastern European Thought, $70(4), 235-247$.

Chalmers, A. (1982). What is this thing called science?. Milton Keynes: Open University Press.

Colletti, L. (1996). End of philosophy and other essays. Rome: Ideazione.

\footnotetext{
7 The primary documents and proceedings of the first four congresses of the Communist International make this evident. See Riddell (1987, 1991, 2012, 2015).
} 
Coombs, N. (2016). Did Lenin refound Marxist dialectics in 1914? The European Legacy, 21(1), 1-18.

Cornforth, M. (1980). Communism and philosophy: Contemporary dogmas and revisions of Marxism. London: Lawrence and Wishart.

Dunayevskaya, R. (1973). Philosophy and revolution: From Hegel to Sartre, and from Marx to Mao. New York: Delacorte Press.

Femia, J. (1993). Marxism and democracy. Oxford: Clarendon Press.

Harding, N. (1996). Leninism. London: Macmillan.

Horkheimer, M. (1987). Gesammelte Schriften (Vol. 11). Frankfurt am Main: Fischer Verlag.

Hunt, R. (1950). The theory and practice of communism. London: Geoffrey Bles.

Jordan, Z. (1967). The evolution of dialectical materialism. New York: St. Martin's Press.

Kolakowski, L. (1978). Main currents of Marxism. New York: W. W. Norton and Company.

Korsch, K. (1970). Marxism and philosophy. New York: Monthly Review Press.

Korsch, K. (1975). Lenin's philosophy. In A. Pannekoek (Ed.), Lenin as philosopher (pp. 109-120). London: Merlin Press.

Lenin, V. (1977). Collected works. London: Lawrence and Wishart.

Liebman, M. (1975). Leninism under Lenin. London: Merlin Press.

Mayer, R. (1999). Lenin and the practice of dialectical thinking. Science and Society, 63(1), 40-62.

Meyer, A. (1957). Leninism. New York: Praeger.

Michael-Matsas, S. (2007). Lenin and the path of dialectics. In S. Budgen, S. Kouvelakis, \& S. Zizek (Eds.), Lenin reloaded: Toward a politics of truth (pp. 101-120). Durham: Duke University Press.

O’Neill, J. (1996). Engels without dogmatism. In C. Arthur (Ed.), Engels: A centenary appreciation (pp. 47-67). Houndmills: Macmillan Press.

Pannekoek, A. (1975). Lenin as philosopher. London: Merlin Press.

Plamenatz, J. (1954). German Marxism and Russian communism. London: Longman's Green.

Popper, K. (1962). The open society and its enemies. London: Routledge and Kegan Paul.

Popper, K. (1972). Objective knowledge. Oxford: Clarendon Press.

Read, C. (2005). Lenin: A revolutionary life. Abingdon: Routledge.

Riddell, J. (Ed.). (1987). The Communist International in Lenin's time, Vol. 3: Founding the communist international: Proceedings and documents of the first congress: March 1919. New York: Pathfinder Press.

Riddell, J. (Ed.). (1991). The communist international in Lenin's time: Workers of the world and oppressed peoples unite! Proceedings and documents of the second congress, 1920. In two volumes. New York: Pathfinder Press.

Riddell, J. (Ed.). (2012). Toward the united front: Proceedings of the fourth congress of the communist international, 1922. Chicago: Haymarket Books.

Riddell, J. (Ed.). (2015). To the masses: Proceedings of the third congress of the communist international, 1921. Chicago: Haymarket Books.

Ruben, D. (1977). Marxism and materialism: A study in marxist theory of knowledge. Sussex: The Harvester Press.

Ryan, J. (2012). Lenin's terror: The ideological origins of early soviet state violence. London: Routledge.

Service, R. (1985). Lenin: A political life (Vol. 1). Houndsmills: Macmillan.

Shandro, A. (2014). Lenin and the logic of hegemony. Chicago: Haymarket Books.

Sheehan, H. (1993). Marxism and the philosophy of science. New York: Humanity Books.

Thomas, P. (1976). Marx and science. Political Studies, 24, 1-23.

Tucker, R. (Ed.). (1975). The Lenin anthology. New York: W. W. Norton and Company.

Wolfe, B. (1965). Marxism: One hundred years in the life of a doctrine. New York: The Dial Press.

Wolfe, B. (2001). Three who made a revolution. New York: Cooper Square Press.

Yushkevich, P. (1910). Pillars of philosophical orthodoxy. Cited in H. Sheehan. (1993). Marxism and the Philosophy of Science. New York: Humanity Books.

Zizek, S. (1997). Repeating Lenin. Marxists Internet Archive. https://www.marxists.org/reference/subje ct/philosophy/works/ot/zizek1.htm. Cited 10 September, 2018.

Zizek, S. (2002). A plea for Leninist intolerance. Critical Inquiry, 28(2), 542-566.

Publisher's Note Springer Nature remains neutral with regard to jurisdictional claims in published maps and institutional affiliations. 